\title{
Studi Komparatif Tingkat Adversity Quotient Berdasarkan Pangkat Anggota (Member) HNI-HPAI
}

\author{
Sugeng Saputra ${ }^{1}$, Dery Kurniawan ${ }^{2}$, M. Hubbal Khair ${ }^{3}$ \\ ${ }^{1,2,3}$ Magister Psikologi, Universitas Islam Negeri Sultan Syarif Kasim Riau \\ sugengsaputra36@gmail.com
}

\begin{abstract}
Abstrak
Di zaman serba digital saat ini, proses memperoleh informasi tentang dunia pekerjaan menjadi semakin mudah, tetapi dibalik kemudahan mencari informasi tersebut, tidak diikuti dengan ketersediaan tempat bekerja yang sesuai dengan yang dibutuhkan. Imbasnya adalah timbul persaingan yang sangat ketat bagi para calon pekerja. Untuk perusahaan, hal seperti ini tentu sangat menguntungkan, karena perusahaan bisa dengan leluasa memilih karyawan terbaiknya. Sementara bagi para calon pekerja yang tidak diterima atau tersingkir dari persaingan tadi, bila tidak ditangani dengan baik akan timbul satu angkatan baru atau yang biasa kita sebut dengan pengangguran. Di tengah kegaduhan ekonomi tadi, maka muncul HNI-HPAI sebuah gerakan bisnis baru, yang fokus utama dari gerakan bisnis ini, menciptakan sebuah kesadaran tentang pentingnya menggunakan produk-produk yang jelas kehalalannya. Di tengah pandemi yang melanda saat ini, banyak bisnis yang gulung tikar dan memberhentikan para karyawannya. Sementara di HNI-HPAI banyak orang mampu bertahan dan sukses dalam menjalankan bisnis ini. Tujuan penelitian ini adalah untuk mengetahui seberapa besar perbedaan tingkat adversity quotient berdasarkan pangkat pada member HNI-HPAI. Metode yang digunakan dalam penelitian ini adalah metode penelitian kuantitatif dengan menggunakan uji anova sebagai teknik analisis data. Penelitian ini dilakukan pada 93 member HNI-HPAI, dengan menyebarkan skala adversity quotient melalui google form. Dari penelitian ini diperoleh hasil perbedaan yang signifikan tingkat adversity quotient, ditinjau dari pangkat ke agenan HNI-HPAI. Yang mana terjadi perbedaan yang cukup signifikan dari member berpangkat tertinggi dengan member berpangkat terendah. Selain itu,hasil dari kategorisasi diketahui rata-rata member HNI-HPAI memiliki tingkat adversity quotient yang sedang.
\end{abstract}

Kata kunci: Adversity Quotient, Halal Network Internasional (HNI)

\begin{abstract}
In today's digital era, the process of obtaining information about the world of work is getting easier, but behind the ease of finding this information, it is not followed by the availability of a place to work that suits what is needed. The impact is that there is very tight competition for prospective workers. For companies, things like this are certainly very profitable, because companies can freely choose their best employees. Meanwhile, for prospective workers who are not accepted or eliminated from the competition, if not handled properly, a new generation will emerge or what we usually call unemployment. In the midst of the economic upheaval, the HNIHPAI emerged, a new business movement, which was the main focus of this business movement, creating an awareness of the importance of using products that were clearly halal. In the midst of the current pandemic, many businesses are closing their doors and laying off their employees.
\end{abstract}


While in HNI-HPAI, many people are able to survive and be successful in running this business. The purpose of this study was to determine how much difference the adversity quotient level is based on the rank of the HNI-HPAI members. The method used in this research is quantitative research methods using the ANOVA test as a data analysis technique. This research was conducted on 93 HNI-HPAI members, by distributing the adversity quotient scale via google form. From this study, the results obtained a significant difference in the level of adversity quotient, in terms of rank to the HNI-HPAI agent. Which is a significant difference between the highest-ranking members and the lowest ranking members. In addition, the results of the categorization show that the average HNI-HPAI member has a moderate adversity quotient.

Keywords: Adversity Quotient, Halal Network Internasional (HNI)

\section{Pendahuluan}

Dizaman serba digital saat ini, proses memperoleh informasi tentang dunia pekerjaan menjadi semakin mudah, tetapi dibalik kemudahan mencari informasi tersebut, tidak diikuti dengan ketersediaan lapangan pekerjaan yang sesuai dengan yang dibutuhkan. Karena ketersediaan lapangan pekerjaan yang sedikit, maka para pencari kerja harus bisa kreatif, dan berusaha untuk menciptakan lapangan pekerjaannya sendiri, dan memang sudah saatnya untuk merubah mindset yang awalnya berorientasi pada job seeker dan beralihke pada job creator atau berbisnis (Suharti \& Sirine, 2011). Dari berbagai macam bisnis yang beredar, ada sebuah gerakan bisnis baru, yang fokus utama dari gerakan bisnis ini adalah, menciptakan sebuah kesadaran tentang pentingnya menggunakan produk-produk yang jelas kehalalannya dan kualitasnya (HNI).

Ditengah pandemi yang melanda saat ini, banyak bisnis yang gulung tikar dan memberhentikan sepihak para karyawannya. Sementara di HNI-HPAI banyak orang mampu bertahan dan sukses dalam menjalankan bisnis ini. Kemampuan bertahan ini lah yang menurut Stoltz (2000) disebut dengan adversity quotient.

Kemudian Stoltz menjelaskan adversity quotient memiliki 3 bentuk, yaitu:

a). Adversity quotient sebagai kerangka kerja konseptual yang baru untuk memahami dan meningkatkan semua segi kesuksesan.

b). Adversity quotient adalah suatu ukuran untuk mengetahui respon terhadap tantangan kerja.

c). Adversity quotient adalah serangkaian peralatan yang memiliki dasar ilmiah untuk memperbaiki respon terhadap kesulitan, yang akan berakibat memperbaiki efektivitas pribadi dan professional secara keseluruhan.

Dari penjelasan di atas, maka apabila para individu ingin sukses, salah satu indicator psikologi yang harus dimiliki adalah adversity quotient, agar ketika individu dihadapkan dengan permasalahan, dapat merespon permasalahan tersebut dengan positif. Kemudian, pernyataan ini diperkuat kembali oleh penelitian yang dilakukan oleh Hutagalung (2018) menemukan bahwa adversity quotient berpengaruh secara positif terhadap kehidupan berwirausaha. 


\section{Adversity Quotient}

Stoltz (2000) berpendapat bahwa adversity quotient adalah kemampuan seseorang dalam mengubah persoalan menjadi sebuah kesempatan. Sementara Markman (dalam Puri, 2012) adversity quotient adalah pengetahuan tentang ketahanan individu, individu yang secara maksimal menggunakan kecerdasan ini akan menghasilkan kesuksesan dalam menghadapi tantangan, baik itu besar ataupun kecil dalam kehidupan sehari-hari.SedangkanSurekha (2001) menyatakan bahwa adversity qoutient adalah kemampuan berfikir, mengelola dan mengarahkan tindakan yang membentuk suatu pola-pola tanggapan kognitif dan perilaku atas stimulus peristiwa-peristiwa dalam kehidupan yang merupakan tantangan atau kesulitan.

Lebih lanjut Stoltz (2000) menyatakan, adversity quotient mempunyai tiga tingkatan, yaitu quitter, camper dan climber. Adapun penjelasan dari ketiga tingkatan AQ tersebut yaitu:

a) Quitter atau orang yang mudah menyerah, yaitu orang yang mundur dari pendakian mereka atau pencapaian tujuan mereka. Orang yang seperti ini mudah putus asa dan cepat menyerah.

b) Campers atau orang yang berkemah, yaitu orang yang bekerja keras, menggunakan potensinya untuk mengatasi kesulitan yang dihadapi, dan kemudian merasa puas dengan zona aman yang mereka jumpai. Mereka jadi termotivasi oleh hal-hal yang dapat diperkirakan, keamanan dan perubahan terbatas, sehingga mereka dan kemampuan mereka akan mengalami kemunduran. Dengan kata lain orang yang tipe seperti ini tidak mencapai puncak namun sudah puas dengan apa yang dicapainya.

c) Climber atau pendaki, yaitu orang yang terus mendaki, terus berusaha dengan segenap kemampuan yang dimilikinya untuk mengatasi kesulitannya dan mencapai potensi maksimalnya. Climber akan terus berusaha, terus belajar dan tidak pernah puas dengan apa yang diraihnya. Dengan kata lain, orang yang tipe seperti ini adalah orang yang selalu optimis, melihat peluang-peluang, melihat celah dan selalu bergairah untuk terus maju.

\section{HNI- HPAI}

PT Herba Penawar Alwahida Indonesia, yang kemudian dikenal sebagai HPAI, merupakan salah satu perusahaan Bisnis Halal Network di Indonesia yang fokus pada produk-produk herbal. HPAI, sesuai dengan akta pendirian Perusahaan, secara resmi didirikan pada tanggal 19 Maret 2012. HPAI dibangun dari perjuangan panjang yang bertujuan menjayakan produk-produk halal dan berkualitas berazaskan Thibbunnabawi, serta dalam rangka membumikan, memajukan, dan mengaktualisasikan ekonomi Islam di Indonesia melalui entrepreneurship (HPHI, 2015).

Stoltz (2000) menjelaskan bahwa individu yang terindikasi adversity quotientnya rendah, cenderung murung, merasa diri paling malang dan tidak berdaya ketika dihadapkan dengan masalah. Sementara individu yang memiliki adversity quotient 
yang tinggi akan bisa menghadapi berbagai masalah, merespon masalah tersebut dengan positif sehingga keluar dari permasalahan tersebut dan menjadi orang yang sukses.

Dinamika yang terjadi di lapangan, banyak member HNI-HPAI yang berhasil dan sukses, dan banyak pula member yang tidak mengalami perkembangan dalam bisnisnya. Indikasi yang muncul kepada member yang tidak mengalami perkembangan ini adalah dikarenakan rendahnya adversity quotient, karena berdasarkan penelitian yang dilakukan oleh Putri (2013) pada siswa menemukan bahwa semakin tinggi adversity quotient siswa maka semakin tinggi minat berwirausaha siswa, sebaliknya semakin rendah adversity quotient siswa maka semakin rendah minat berwirausaha siswa.

\section{Metode}

Rancangan penelitian yang digunakan dalam penelitian ini adalah jenis penelitian kuantitatif, dengan pendekatan studi komparasi untuk mengetahui perbedaan tingkat adversity quotient berdasarkan pangkat ke agenan pada member HNI-HPAI.

Instrumen penelitian yang digunakan untuk mengukur tingkat adversity quotient pada sampel penelitian, peneliti menggunakan skala adversity quotient yang dikembangkan oleh Stoltz (2000).

Partisipan penelitian ini adalah 93 member HNI-HPAI yang tersebar di Kota Pekanbaru yang dijangkau dengan menggunakan kuesioner daring (google form). Tautan kuesioner daring disebar secara snowball menggunakan relasi hubungan antar peneliti dengan pimpinan cabang distributor HNI-HPAI Kota Pekanbaru untuk dibagikan ke member mereka dalam waktu satu minggu mulai dari 10 Februari 2021 hingga 17 Februari 2021.

Data penelitian yang diperoleh dilakukan tabulasi dan dihitung dengan menggunakan software Statiscal Product and Service Solution (SPSS) 22.00 For Windows. Dengan menggunakan teknik analisa data uji beda One WayAnova.

\section{Hasil}

Tabel 1

Pedoman Kategorisasi Empirik Tingkat Adversity Quotient

\begin{tabular}{cccccc}
\hline Jenis Data & Xmin & Xmax & Range & Mean $(\boldsymbol{\mu})$ & Standar Deviasi $(\boldsymbol{\sigma})$ \\
\hline Empirik & 20 & 80 & 60 & 50 & 14 \\
\hline
\end{tabular}

Berdasarkan Tabel 2 Kategorisasi Tingkat adversity quotientdi atas, diketahui bahwa rata-rata member yang memiliki tingkat adversity quotient rendah berjumlah 0 orang, kemudian member yang memiliki kategorisasi sedang berjumlah 50 orang, 
sedangkan member yang memiliki tingkat adversity quotient yang tinggi berjumlah 43 orang. Maka dapat disimpulkan bahwa rata-rata member HNI-HPAI tingkat adversity quotient berada pada posisi sedang.

Tabel 2

Kategorisasi Tingkat Adversity Quotient

\begin{tabular}{lccc}
\hline \multicolumn{1}{c}{ Kategorisasi } & Nilai & $\begin{array}{c}\text { Jumlah } \\
\text { Karyawan }\end{array}$ & Persentase (\%) \\
\hline Rendah & $\mathrm{X}<29$ & 0 & $0 \%$ \\
Sedang & $29 \leq \mathrm{X}<64$ & 50 & $53,7 \%$ \\
Tinggi & $64 \leq \mathrm{X}$ & 43 & $46.3 \%$ \\
& Total & $\mathbf{9 3}$ & $\mathbf{1 0 0 \%}$ \\
\hline
\end{tabular}

Tabel 3

Perbedaan adversity quotient berdasarkan peringkat

\begin{tabular}{|c|c|c|c|}
\hline Peringkat & Peringkat & Mean & Sig. \\
\hline \multirow[t]{4}{*}{ Agen biasa } & M & .25714 & .916 \\
\hline & SM & -4.14167 & .113 \\
\hline & EM, D, SD & -3.51667 & .210 \\
\hline & ED & $-8.02529^{*}$ & .001 \\
\hline \multirow[t]{4}{*}{ Manajer } & $\mathrm{AB}$ & -.25714 & .916 \\
\hline & SM & -4.39881 & .069 \\
\hline & EM, D, SD & -3.77381 & .151 \\
\hline & ED & $-8.28243^{*}$ & .000 \\
\hline \multirow[t]{4}{*}{ Senior Manajer } & $\mathrm{AB}$ & 4.14167 & .113 \\
\hline & M & 4.39881 & .069 \\
\hline & EM, D, SD & .62500 & .820 \\
\hline & ED & -3.88362 & .086 \\
\hline \multirow[t]{4}{*}{$\mathrm{EM}, \mathrm{D}, \mathrm{SD}$} & $\mathrm{AB}$ & 3.51667 & .210 \\
\hline & M & 3.77381 & .151 \\
\hline & SM & -.62500 & .820 \\
\hline & ED & -4.50862 & .071 \\
\hline \multirow[t]{4}{*}{ ED } & $\mathrm{AB}$ & $8.02529^{*}$ & .001 \\
\hline & $\mathrm{M}$ & $8.28243^{*}$ & .000 \\
\hline & SM & 3.88362 & .086 \\
\hline & EM, D, SD & 4.50862 & .071 \\
\hline
\end{tabular}

Berdasarkan Tabel 3 Perbedaan adversity quotient berdasarkan peringkat kita memperoleh data bahwahanya yang pangkatnya $\mathrm{AB}$, dan Manajer saja yang terdapat perbedan yang cukup signifikan terhadap ED (pangkat tertinggi HNI).

\section{Pembahasan}


Di HNI-HPAI pangkat yang paling tinggiitua dalah Eksekutif Direktur (ED) atau biasa di sebut dengan Leader/ Pimpinan dan pangkat paling rendahnya itu adalah agen biasa $(\mathrm{AB})$ kemudian Manajer $(\mathrm{M})$. Berdasarkan hasil penelitian yang dipaparkan di atas, diketahui bahwa terdapat perbedaan yang signifikan antara pangkat tertinggi dengan pangkat yang paling rendah, dari data signifikan yang terpapar keduanya menunjukan 0.001 untuk pangkat $\mathrm{ED}$ ke $\mathrm{AB}$ dan 0.000 dari $\mathrm{ED}$ ke $\mathrm{M}$ yang artinya memenuhi criteria $<0,05$. Oleh karena itu para ED ini terindikasi memiliki adversity quotient yang tinggi, pendapat ini diperkuat oleh temuan dari Markman (2002) bahwa para pemilik atau pimpinan perusahaan akan memiliki keinginan yang kuat untuk mengembangkan kemampuan daya juangnya dalam mengontrol situasi yang terjadi pada suatu perusahaan dari pada karyawan yang bekerja pada perusahaan tersebut.

Penelitian yang juga telah dilakukan Kusuma (2004) dan Laura \& Sunjoyo (2009) mengemukakan hasil penelitian bahwa individu yang memiliki AQ tinggi dapat meningkatkan kinerjanya. Individu dengan AQ tinggi dapat mencapai kesuksesan, karena individu memiliki semangat untuk terus belajar untuk dapat meningkatkan kinerjanya. Individu dengan AQ rendah tidak dapat meningkatkan kinerjanya, karena tidak memiliki kemampuan untuk bertahan dalam kesulitan.

Stoltz (2000) mengungkapkan bahwa mereka yang mempunyai Adversity Quotient yang tinggi akan merespon kesulitan sebagai sesuatu yang sifatnya eksternal, sementara, dan terbatas, serta optimis dalam menjalani hidup. Mereka disebut oleh Stoltz sebagai Climbers. Climbers selalu menyambut tantangan-tantangan yang disodorkan kepadanya. Climbers yakin bahwa segala hal bisa ia lakukan dan akan terlaksana. Mereka bisa memotivasi diri sendiri, memiliki semangat tinggi, dan berjuang untuk mendapatkan yang terbaik dari hidup.Climbers memahami bahwa kesulitan adalah bagian dari hidup.

KemudianStoltz (2000) menjelaskan bahwa dalam adversity itu terbagi dalam tiga tingkatan, tingkatan terendah dinamakan dengan quitter, kemudian yang menengah disebut camper dan yang paling tinggi climber. Tipe climbers (pendaki) diibaratkan sebagai tipe yang selalu berupaya mencapai puncak kebutuhan aktualisasi diri pada skala hirarki Maslow. Orang dengan tipe climbers adalah tipe manusia yang berjuang seumur hidup, tidak perduli sebesar apapun kesulitan yang datang.

Dari hasil penelitian juga dapat diketahui bahwa sebagian kecil subjek penelitian mempunyai Adversity Quotient tinggi, artinya sebagian kecil subjekpenelitian memiliki kemampuan yang tinggi dalam bertahan dan mengatasi kesulitan serta tantangan hidup yang dihadapi. Tingginya kemampuan AdversityQuotient yang dimiliki oleh sebagian besar subjek penelitian tersebut dapat dilihat dalam 4 aspek yang membentuk Adversity Quotient seseorang.

Pertama, aspek Control. Subjek penelitian yang mempunyai skor control tinggi berarti subjek tersebut merasakan kendali yang besar terhadap peristiwa-peristiwa yang menimbulkan kesulitan. Semakin besar kendali yang dirasakan maka semakin besar kemungkinannya bertahan menghadapi kesulitan-kesulitan,dan tetap teguh dalam 
pendekatan mencari penyelesaian masalah.

Kedua aspek Origin dan Ownership. Subjek penelitian yang mempunyai skor Origin dan Ownership tinggi berarti subjek penelitian tersebut mempunyai kemampuan untuk menghindari perilaku menyalahkan diri sendiri yang tidak perlu sambil menempatkan tanggung jawab diri sendiri pada tempatnya yang tepat. Semakin tinggi skor Origin dan Ownership subjek, semakin besar dirinya mengakui akibat-akibat dari suatu perbuatan apapun penyebabnya, sehingga dapat memberikan kontribusi yang besar dalam menghadapi masalah.

Ketiga aspek Reach. Subjek penelitian mempunyai skor Reach yang tinggi menunjukkan bahwa subjek tersebut merespons kesulitan sebagai sesuatu yang spesifik dan terbatas. Membatasi jangkauan kesulitan memungkinkan untuk berpikir jernih dalam mengambil keputusan-keputusan dan tindakan dalam menyelesaikan masalah.

Keempat, aspek Endurance. Subjek penelitian yang mempunyai skor Endurance tinggi berarti subjek tersebut memandang kesulitan dan penyebabpenyebabnya sebagai sesuatu yang bersifat sementara, cepat berlalu dan kecil kemungkinannya terjadi lagi. Hal ini akan meningkatkan energi, optimisme, dan memungkinkan subjek untuk bertindak mencari penyelesaian masalah.

Menggambarkan profil AQ dari kalangan anggota perusahaan seperti karyawan hingga ke jajaran yang lebih tinggi umumnya berdasarkan pengembangan dari Stoltz terletak dari lima dimensi atas AQ itu sendiri, yaitu Control, Origin, Ownership, Reach, dan Endurance. Salah satu periset yang turut mengkaji paradigma terkait AQ meringkas dimensi-dimensi tersebut menjadi empat, yang disingkatnya menjadi $\mathrm{CO}_{2} \mathrm{RE}$ (Poolkha, 2012). Poolkha menyandingkan Origin dengan Ownership sebagai dua dimensi yang berkaitan satu dengan yang lainnya.

Dari yang telah ditemukan pada riset tersebut, hasil AQ akan terlihat berbeda dari tiap level anggota di sebuah perusahaan atau organisasi. Bahkan dari anggota dalam satu level di sebuah perusahaan tingkat AQ dapat berbeda dengan anggota yang lainnya. Stoltz menggambarkan secara hirarkis tingkat kesulitan atas tiga kesulitan, dari yang terbawah adalah kesulitan individual, lalu yang menengah adalah kesulitan tempat bekerja, dan yang paling atas adalah kesulitan sosial. Tiap para jajaran dari pelaku organisasi dan perusahaan akan menemukan kesulitannya sesuai dengan apa yang dimiliki dari AQ nya. Mungkin saja, semakin tingginya AQ seseorang dalam pekerjaan maka semakin meningkat juga tingkat kesulitan yang akan dihadapinya. Oleh karenanya, tiap dari posisi atau jabatan akan menggambarkan tingkat AQ yang dimiliki. Penemuan riset AQ mengemukakan adanya dorongan minat entrepreneur terhadap AQ (Shohib, 2013).

Level bawah seperti karyawan bilamana didapatkan AQ yang tinggi justru cenderung menyokong kemajuan perusahaan tempat ia bekerja. Dalam artian, karakter

AQ pada karyawan tersebut memiliki AQ yang tinggi meski bukan tipe climber dapat dijelaskan analisanya dari dimensi AQ, seperti batasan yang ia pahami dan ia sesuaikan dengan dirinya (tipe camper). berbeda dengan pemahaman zona nyaman, 
karyawan dengan karakter tersebut dalam menggambarkan AQ nya meletakkan kontrol apa yang ia sanggup untuk ketahanannya dan apabila mendapatkan kesulitan dari apa yang ia takar sebelumnya maka penjelasan selanjutnya dapat kita simak dari uraian Stoltz (dalam Poolkha, 2012).

Ketika orang harus behenti dari kebiasaan melakukan hal-hal yang sudah biasa dilakukan, maka keseimbangannya menjadi terganggu, status quo yang ia miliki menjadi terganggu, metode lama, perilaku, prosedur hingga apa yang menjadi prinsipnya akan berakhir. Tahap itu merupakan akhiran. Kemudian, dilanjutkan pada tahap transisi, dimana dalam tahap ini orang mulai menyikapi akan perubahan yang ada dalam dirinya. terakhir adalah tahap awal yang baru, di mana dari lamanya fase transisi, orang tersebut mengadopsi metode baru, memunculkan perilaku yang baru sebagai penyelesaiannya terhadap kesulitan. Sehingga, dapat dipahami keterkaitan antara tingkat kesulitan dengan dimensi AQ dari tiap-tiap anggota sebuah organisasi atau perusahaan.

\section{Kesimpulan}

Berdasarkan hasil penelitian dapat disimpulkan bahwa terdapat perbedaan yang signifikan tingkat adversity quotient, ditinjau dari pangkat ke agenan HNI-HPAI. Yang mana terjadi perbedaan yang cukup signifikan member dengan pangkat tertinggi dengan pangkat terendah. Selain itu dari hasil kategorisasi diketahui rata-rata member HNI-HPAI memiliki tingkat adversity quotient yang sedang.

\section{Referensi}

HPHI. (2015). Profil Perusahaan. Diunduh dari http://hpaindonesia.net/v3/profilperusahaan/ di akses pada 23/02/021.

Hutagalung. (2018). Pengaruh Adversity Quotient Terhadap Keberhasilan Usaha Pusat Industri Kecil Medan Denai. Jurnal Pendidikan kewirausahaan Indonesia.

Kusuma, I. H. (2004). Studi korelasional antara kecerdasan adversity dan motivasi berprestasi dengan kinerja kepala sekolah di lingkungan yayasan BPK penabur Jakarta. Jurnal Pendidikan Penabur, 02(2),17-34.

Laura, \& Sunjoyo. (2009). Pengaruh adversity quotient terhadap kinerja karyawan: sebuah studi kasus pada holiday inn Bandung. Proceeding of the 2nd National Symposium on May 30th (pp. 368-393). Bandung: Universitas Kristen Maranatha.

Markman, G. D., Gianiodis, P. T., Phan, P. H., \& Balkin, D. B. (2005). Innovation speed: Transferring university technology to market. Research Policy, 34(7), 1058-1075.

Markman, Gideon D. (2002). AQ: The Role of Personal Bounce-Back in New Venture Formation. Diunduh dari http//www.peaklearning.com. 
Phoolka, E. S., \& Kaur, N. (2012). Adversity Quotient: A new paradigm to explore. Contemporary Business Studies, 3(4), 67-78.

Putri, S. Y. (2013). Hubungan adversity quotient denganminatberwirausahasiswakelas XII pemasaran di SMKN 1 surabaya. Jurnal Pendidikan Tata Niaga (JPTN). Vol 01, No. 01, 1-15.

Shohib, M. (2013). Adversity quotient dengan minat entrepreneurship. Jurnal Ilmiah Psikologi Terapan, 1(1), 32-39.

Stoltz, PG. (2000). Adversity Quotoient, Mengubah Hambatan Menjadi Peluang (diterjemahkan oleh T Hermaya). Jakarta: PT Gramedia Widiasarana Indonesia.

Suharti, L., \&Sirine, H. (2011). Faktor - Faktor Yang Berpengaruh Terhadap Niat Kewirausahaan (Entrepreneurial Intention): Studi Terhadap Mahasiswa Universitas Kristen Satya Wacana Salatiga. Jurnal Manajemen dan Kewirausahaan, 124-134.

Surekha. (2001). Adversity Intellengence. Pustaka Umum: Jakarta.

Wisesa. (2016). Hubungan Adversity Quotient Dengan Motivasi Berwirausaha Pada Mahasiswa Universitas Udayana Yang Mengikuti Program Mahasiswa Wirausaha. Jurnal Psikologi Udayana. Vol. 3, No. 2, 187-195 